\title{
УНКЯР-ИСКЕЛЕСИЙСКИЙ ДОГОВОР ПО «ЗАПИСКАМ» Н. Н. МУРАВЬЕВА
}

\section{С. И. Муртузалиев}

Муртузалиев С. И. Ункяр-Искелесийският договор по „Записките“ на Н. Н. Муравьов. Дипломатическата мисия на генерала не само подготвя, но и съдейства за подписването на примирието и за Ункяр-Искелесийския договор. Мемоарите му „Руснаците на Босфора през 1833 г.“ доказват, че помощ на Турция е оказана по молба на султана и че споразумението не му е било натрапено от Русия. Аргументите на Муравьов за липсата на гаранции за безопасността на Черноморското крайбрежие изглеждат обосновани. След Одринския мирен договор (1829) проблемите на Балканите отстьпват на втори план в политиката на Руската империя.

Ключови думи: спомени; генерал Муравьов; Русия; Турция; Ункяр-Искеселийски договор.

Муртузалиев С. И. Ункяр-Искелесийский договор по «Запискам» Н.Н. Муравьева. Дипломатическая миссия генерала не только подготовила, но и предвосхитила заключение перемирия и Ункяр-Искелесийского договора. Мемуары «Русские на Босфоре в 1833 г.» убеждают в том, что помощь Турции была оказана по просьбе султана и соглашение не было ему навязано. Доводы Муравьева об отсутствии надежных гарантий безопасности Черноморского побережья представляются обоснованными. После Адрианопольского мира 1829 г. проблемы Балкан для российского царизма отошли на второй план.

Ключевые слова: мемуары; генерал Муравьев; Россия; Турция; Ункяр-Искелесийский договор.

Murtuzaliev S. I. The Treaty of Hünkâr İskelesi according to "Notes" of N. N. Muravyov. The general's diplomatic mission is a successful one in the process of working on the ceasefire and on the future treaty of Hünkâr İskelesi. His memoirs "Russians on the Bosphorus in 1833" prove that Russia has supported Turkey following the Sultan ask for help, so the treaty has not been a dictate of Russia. Muravyev's arguments on the miss of hopeful guaranties for the security of the Black Sea seaside seem to be enough serious. After the Adrianopole treaty of 1829 the problems of the Balkans are not so actual for Russian Empire as earlier.

Keywords: memoirs; general N. N. Muravyov; Russia; Turkey; Treaty of Hünkâr İskelesi.

Россию и Турцию связывает многовековая и весьма непростая история - они пережили десяток русско-турецких войн. Вместе с тем в истории взаимоотношений этих евразийских империй известны и периоды, когда они объединялись для борьбы с общим противником, как, к примеру, это произошло во время египетского кризиса 1831-1833 гг., когда император Николай I поддержал турецкого султана Махмуда II против взбунтовавшегося египетского паши Мехмеда (Мегмет, Мухаммед, Муххамед)-Али, заключив оборонительный союз, вошедший в историю под названием Ункияр-Искелесийский договор 1833 г.

Договору предшествовало обострение отношений между Египтом и Турцией. В 1832 г. правитель Египта Мехмед Али-паша восстал против своего повелителя султана Махмуда. Египетские сухопутные войска разбили турок под Гомсом и стали продвигаться в Анатолию. Турецкая эскадра была блокирована египетским флотом. Усиление Египта было не в интересах России. Для урегулирования военного конфликта Николай I посылает Н.Н. Муравьева, известного своей смелостью, решительностью и хорошим знанием восточных языков.

Генерал Николай Николаевич Муравьев-Карский (1794-1866) оставил нам один из интереснейших источников тех событий - книгу «Русские на Босфоре в 1833 году» ${ }^{1}$, которая является главным объектом нашего внимания. Поскольку в книге Муравьева события датированы по юлианскому календарю, в скобках они приведены по новому стилю. Автор мемуаров редактировал свои дневниковые записи по прошествии многих лет, что не могло не сказаться на субъективных характеристиках и оценках описываемых действующих лиц, как и на изображении «себя любимого» в исторической «картине маслом», в которой кисть Муравьева играла далеко не последнюю роль. 
По версии Муравьева один только император Николай I прозорливо «постиг последствия, которые могли произойти от ослабления Порты после Адрианопольского мира (1829 г. - С. М.). ... Он один, и вопреки всеобщего мнения, увидел необходимость совершенно изменить относительно Турции политическую ситуацию, существовавшую со времен Петра Великого» (с. 1). Министр же иностранных дел граф К.В. Нессельроде был всего лишь «исполнителем ... мыслей Государя, коих пользы, он, казалось, не признавал» (c. 3). А граф А.Ф. Орлов говорил генералу, что «сам не постигает цели, и какого можно ожидать ... успеха, но что на сие была ... воля Государя» (с. 7).

Во время аудиенции (3 октября) Николай I заявил Муравьеву, что не хотел бы «посылать войска» и желает, чтобы «распря их кончилась. Султан-Махмуд корчит Петра Великого, да неудачно... Мне очень выгодно, чтоб он сидел на турецком престоле», т.к. среди «Моих Крымских Татар... распущены песни с пророчествами о скором прибытии Мегмед-Алипаши (Мехмеда-Али. - С. М.), как заступника православных (надо - правоверных. - С. М.) Мусульман», в связи с чем в Крыму «надобно будет усилить ... число войск» (с. 10).

1 ноября Муравьев получил инструкцию и запечатанное письмо от императора к султану и дополнение к инструкции от Нессельроде. «Из всех приложенных ... бумаг легко усматривается, - пишет Муравьев, - что Министерство Иностранных дел совершенно устраняло себя от какого-либо официального участия в сем деле и не принимало на себя никаких с пашою письменных сношений», которыми бы Муравьев признавался доверенным лицом Николая I. Генерал должен был подписать и саму декларацию, в которой, заметим, Адрианопольский трактат не упоминался «как бы во избежание последствий от предвидевшейся неудачи, которых никто на себя не хотел принять» (с. 14).

Посольство генерала готовилось в тайне и об истинной его цели в Петербурге ходили разные слухи. Чтобы скрыть истинный маршрут следования, Муравьев взял две подорожные - одну до Твери, а другую в Тульчин, и 5 ноября 1832 г. в полночь покинул Петербург.

9 декабря 1832 г. фрегат Муравьева наконец-то прибыл в Стамбул, и он явился к российскому посланнику А.Л. Бутеневу, который принял «деятельное и полезное участие в тогдашних делах Турции и Египта» (с. 26). Перед Бутеневым и генералом стояла сложная задача: «Порте надобно было вселять доверие, между тем не принимать без приглашения участия в делах ее; надобно было представить ей о предложенной помощи флотом, но не предлагать его. Египетского пашу надобно было стращать и застрашить (запугать. - С. М.), но чем? - не известно; надобно было грозить, но обойтись ласково и одними убеждениями». Кроме того «нужно было решить, следует ли при первом свидании с турецкими сановниками объявить им» о готовности Черноморского флота к отплытию, «по требованию султаном помощи» (с. 30-31).

15 декабря во время аудиенции у султана Муравьев дословно сообщил, что именно Николай I поручил ему сказать Мехмеду-Али: «Государь - враг мятежа и друг вашего величества; что если паша, упорствуя в неповиновении вам, станет продолжать военные действия, то он будет иметь дело с Россией» и что ему (генералу) не должно «входить в какие-либо переговоры с восставшим пашей», т.к. от Мехмеда-Али требуется верноподданческое повиновение «своему законному государю» - султану, что очень обрадовало последнего (с. 54).

После долгих проволочек со стороны турок 23 декабря Муравьев наконец-то покинул Царьград (с. 77), и 1 января 1833 г. его фрегат прибыл в Александрию. При входе в порт «никаких взаимных салютов с чьей-либо стороны не было сделано. Обоюдное молчание наше достаточно обнаружило всем, что российский фрегат прибыл не с дружелюбными предложениями».

2 января Муравьев встретился с Мехмед-Али-пашей и устно сообщил ему волю Николая I. Паша «с замешательством просил ... сообщить ему о предмете приезда ... письменно», на что генерал отвечал, что не может «того сделать, потому что самое поручение дано Государем лично и изустно» и что паше «должно прекратить кровопролитие и приступить к мерам примирения с Султаном» (с. 95). Паша попросил время подумать. По настоянию Муравьева следующая встреча с пашой состоялась 4 января, во время которой он вновь и с большей настойчивость повторил слова императора. Встревоженный паша тут же в присутствии генерала велел написать сыну Ибрагиму-паше приказ о немедленном прекращении военных действий, приложил к нему печать и велел приказ быстрее 
отправить. Видно было, что паша согласился вопреки собственного желания и просил 20 дней, чтобы приказ достиг всех отдельных частей его войск, объяснив это тем, что не хотел бы «ответствовать перед Государем ... за все то, что могло бы случиться до 21 дня, считая с сегодняшнего после этого же срока, я принимаю уже на себя ответственность малейшего движения войск».

В ходе дальнейшей беседы паша неоднократно просил «покровительство России в предстоящих ему переговорах с Султаном». На что Муравьев отвечал, что никакой речи о посредничестве быть не может. «Хитрые речи паши» дали генералу повод «усомниться в немедленном отправлении приказа к войску», и он употребил все меры, чтобы удостовериться, что «повеление ... было послано в тот же день с летучей почтой, сухим путем через Сирию; а на другой день отправлен дубликат» (с. 108-117).

Таким образом, дела Муравьева в Египте были окончены, но ветер не позволил сразу отплыть обратно в Царьград. 6 января он получил известие, что «в последствие какогото сильного брожения умов, оказавшегося в столице (Стамбуле. - С. М.), Султан (турецкий. - С. М.) решился немедленно отправить в Египет Галиль-пашу с полномочием для переговоров и заключения условия, от чего Мегмет-паша был в восхищении». Генерал сообщает о слухах, которые ему доставили в тот же день с берега: «В кофейных домах ... толковали, что Государь убедил будто через меня Мегмет-Али к миру, и что я при этом случае выговорил у него во владение России остров Кипр и Иерусалим. При дворе Паши говорили, что Султан заключил чрез мое посредство с Россией трактат оборонительного и наступательного союза, чего он сам весьма желал; но что при рассмотрении дела в Государственном Совете, улемы (духовные лица) не согласились и изорвали трактат, что и побудило Султана послать Галиль-пашу в Египет» (с. 128-129). Если это отвечает действительному положению вещей, получается, что миссия Муравьева не только подготовила, но и предвосхитила заключение весьма выгодного для России Ункяр-Искелесийского оборонительного договора с Турцией.

Пребывая в Александрии, Муравьев получает известие «об условии, заключенном Пашей с двумя английскими купеческими судами, коими они обязались перевозить войска и снаряды в Тарсус» и о том, что «подобные договоры были сделаны Пашей с шестью австрийскими и несколькими греческими купеческими судами...». В мемуарах Муравьева записано: «И так дело снова завязывалось. Я не мог оставить сего случая без дознания причин, побудивших Пашу к новому отправлению войск» (с. 130-136). Не желая оставлять без внимания слухи об отправлении войск, Муравьев 8 января отправляется к паше и предлагает объяснить «как представить Государю о вашем поступке, который всячески должен удивить Его величество?». Оправдываясь, паша отвечал, что «эти люди не составляли батальонов, а что они принадлежат к разным командам солдат, оставшихся от выступивших войск, что он не знал куда с ними деваться в Александрии, а потому и отсылает их к своим полкам, и в доказательство того прибавил, что в числе их не имеется ни одного унтер-офицера», но затруднился назвать точную цифру посланных (с. 139). Разговор завершился фразой генерала, что «после примирения Паше предстоит служить государю своему опытными военачальниками» (с. 143).

10 января Муравьеву доставили письмо с извещением о вероломстве турецкого двора, о том, что «французская миссия из Константинополя прислала с Галиль-пашей ... письмо ... на имя Мегмет-Али от 28-го декабря (по старому стилю. - С. М.), из которого следовало, что Порта, склоняясь на убеждение французской миссии, возобновляет предложения о мире с просьбой к этой (французской. - С. М.) миссии, исключительно принять на себя переговоры» (с. 148).

Не имея возможности «исправить ошибочного направления, данного ему (через Галиль-пашу. - С. М.) Портой, по внушениям Французов», 11 января при попутном ветре фрегат Муравьева, сопровождаемый бригом, наконец-то отплыл в Константинополь, не дав салюта: «...фрегат наш отплыл с теми же знамениями угрозы, с коими явился в Александрийский порт, молчанием напоминая Паше о сделанных им обетах. Сим кончились действия мои в Египте, - пишет генерал. «Хитрая изворотливость в речах Мегмед-Али свидетельствовала, сколько ему было неприятно и тяжко покориться воле Государя. ... Царьград был спасен, - Султан удержался на престоле; но он поплатился своей Сирией и Аданою за опрометчивое послание Галиль-паши и за недоверчивость свою к покровительству России» (с. 149-150). 
26 января австрийский интернунций письменно известил Бутенева о том, что «Ибрагим-паша получил повеление от отца остановиться в движении своем к Царьграду, и что он действительно остановился в Кютаиэ». Далее Муравьев пишет: «Я с удовольствием увидел, что поручение мое в Египте имело полный успех и Мегмет-Али сдержал свое слово. ... Направление умов и дел было совершенно иное в сравнении с тем временем, как я оставил Царьград. Недоверчивость Турок к нашему правительству, если несовершенно исчезла, то, по крайней мере, уменьшилась. Таким образом помрачилось тогда влияние Франции в делах Порты и намерения Государя восторжествовали. Блистательный успех сей принадлежит вполне деятельности и умению Бутенева» (с. 156-157).

27 января Муравьев с Бутеневым поехали на «конференцию» к рейс-эфенди. Их приняли в присутственном здании Порты «на половине Пертев-эфенди, Министра Внутренних Дел, - закоснелого врага Русских». Выслушав генерала, поставившего «на вид важность достигнутого успеха, - прекращения военных действий», оба министра «стали сперва отказываться от морского пособия (эскадры и десанта. - С. М.), ими требованного, а после и от сухопутного (войска. - С. М.), говоря, что после обещаний, данных египетским пашой, в них не предстояло более надобности. ... Бутенев, видя двуличное поведение их, отозвался, что отправление войск на помощь Турции, в самом деле, было сопряжено с большими затруднениями и потребовал от них письменного отказа, что Рейсэфенди и обещал сделать». Вечером состоялась встреча с сераскиром, который «был рассудительнее министров» (с. 159-161).

28 числа Муравьев с Бутеневым навестили английского поверенного в делах Мандевиля, прусского посланника, барона Мертенса, которого генерал знал «за орудие Французов», который изложил гостям свою версию прекращения военных действий, присовокупив, «что это было последствием ... настояний» не генерала, а «прибытия Галиль-паши в Александрию». Уязвленный Муравьев замечает: «Ложное известие, сообщенное Мертенсом, было началом козней французской миссии, завидовавшей влиянию России над Пашой. Козни эти, к сожалению, пустили ветви» в Санкт-Петербурге «и, как кажется, в кабинет Государя. И зависть иностранной миссии обратилась в личную зависть некоторых особ ко мне, по случаю удачного окончания дел в Египте» (с. 161-163).

5 февраля в Стамбул прибыл французский посол, вице-адмирал барон Руссен на фрегате «Галатея». Бутенев получил от рейс-эфенди «давно обещанную меморию», в которой он просил отменить прибытие флота, но предлагал «принять втайне ... следующие меры. Содержать Черноморский флот в готовности с тем, чтобы он снялся с якоря тогда только, когда опять потребуется. ... а для довершения всего, принять подобные меры относительно сухопутных войск, требованных на помощь, с тем, чтобы войска сии немедленно тронулись и двигались по Дунаю, где и ожидали бы дальнейших наставлений от их приятеля г. посланника, которого приглашали вступить по сему случаю в сношение с генералом Киселевым». Бутенев просил Порту в дополнение к «мемории, уведомить его, как бы она полагала поступить, если б флот наш вдруг показался у верховья Босфора, его можно было ежечасно ожидать», т.к. сообщение о приостановлении отправки эскадры, посланное «сухим путем», уже не могло застать флот на якоре (с. 178-180).

Несколькими днями раньше (30 января) Муравьев и Бутенев были приняты султаном, который остался доволен результатами миссии генерала и просил его не уезжать в Россию «до совершенного окончания египетских дел» (с. 169-170). 7 февраля Муравьев уведомил Нессельроде о приглашении султана остаться и после этого прекратил официальные сношения с ним, т.к. окончив дело свое, в ожидании ответа из Петербурга, «участвовал в тогдашних дипломатических сношениях с Портой, более как частное лицо по доброму согласию, существовавшему между Бутеневым» и им. Военному министру Муравьев «донес также об окончании возложенного на меня поручения ... тщательно предостерегая всех и в письмах и в депешах, чтобы не основывались на словах Мегмет-Али-Паши» и не полагались на прекращение военных действий, которые он мог ежечасно возобновить» (с. 181).

Утром 8 (20) февраля 1833 г. «мы вдруг узнали, что эскадра наша показалась у верховья Босфора». Эскадрой командовал бывший тогда начальник Черноморского флота, контр-адмирал М.П. Лазарев. Она состояла из 4 линейных кораблей, 3 фрегатов, 1 корвета и 1 брига (с. 184). Появление эскадры «поселило опасение в умах недовольных Турок; число судов во мнении народа было увеличено без меры, и в случае приближения Египтян, никто бы в Константинополе не осмелился восстать против Султана». Султан прислал 
Ахмед-пашу-мушира с изъявлением признательности за участие, принимаемое Николаем I в положении Махмуда II, но вместе с тем была высказана просьба, отослать эскадру в «Сизополь, где бы она стояла в готовности и ожидании новых приказаний, прибыть в Царьград, в случае надобности». На следующий день Муравьев и Бутенев узнали об истинных причинах просьбы турок, обеспокоенных известием, что Ибрагим-паша якобы 11-12 февраля вновь двинул войско (с. 187-189).

О напряженности ситуации, в которой приходилось работать посланнику и генералу, может свидетельствовать следующая большая цитата из мемуаров Муравьева: «13-го февраля Рейс-эфенди письменно уведомил Бутенева, что французский посол принял на себя довершение переговоров между Турцией и Египтом, присовокупив, что посол был извещен о согласии нашем возвратить эскадру в Сизополь. Министр ясно обнаружил участие вице-адмирала Руссена в сношениях наших с Турцией. Я никогда не видел рассудительного и скромного Бутенева в таком негодовании, как он был при получении сей ноты, ибо сердце его чуждалось вероломства и не терпело унижения. Бутеневу еще до того неприятно было видеть изменчивую политику Порты, и он с прискорбием за несколько дней (до этого. - С. М.) согласился на возвращение эскадры; но наглость турецкого правительства, отвергавшее таким образом испрошенное пособие, и возраставшая надменность Французов, хвалившихся влиянием, приобретенным ими в Порте - превышали всякую меру терпения. Посланнику нашему предстояло избрать из двух одно: или следовать буквально повторенным наставлениям министерства, предписывающего отнюдь не навязывать Туркам вооруженного пособия, или, к стыду двора нашего, допустить дерзкие разглашения Французов, что они выслали флот наш из Босфора. Личные правила благородной твердости Бутенева в сем затруднительном случае восторжествовали. Он отвечал Рейс-эфенди, что хотя и не отказывается от данного обещания возвратить эскадру с первым попутным ветром, но не принимает ноты, в которой упоминается об участии какого-либо постороннего посланника в сем деле; что писать о том в официальной бумаге неприлично после великодушия, оказанного Государем, и что призыв эскадры и возвращение ее зависят от одного Султана. С этим ответом он приказал возвратить ноту к Рейс-эфенди и бросить ее к нему на софу, если б он не хотел принять ее обратно. Такой решительный поступок изумил Рейс-эфенди, который в извинение свое отозвался, что нота не им сочинена, а написана в Порте, и что в ней упоминалось о французском после без всякого умысла. Отважный поступок сей сделал тогда решительный переворот в делах политики. Турки не противоречили нам более, и с тех пор не вмешивали подобных обстоятельств в сношениях своих с нами» (с. 190-191).

Повествуя о дальнейшем развитии событий, Муравьев сообщает: «В последних числах февраля получены депеши из Вены. Посланник Татищев уведомлял Бутенева, что Талейран, по случаю возникших дел в Турции, старался составить союз с Англией против России; но что сей союз был прерван действиями князя Меттерниха, и что, напротив того, Лондонский кабинет отправил, по примеру нашему, в Александрию полковника Кампбеля с поручением, подобным моему. Сему же примеру последовал и Австрийский двор, отправив в Александрию полковника Промеша. И так Руссен пока действовал один, неосновательно обещая золотые горы и Турецкому Султану и Египетскому Паше» (c. 201).

О раскладе сил в самой Османской империи красноречиво свидетельствует сюжет с медалями. Во время посещения российскими флотскими офицерами монетного двора (25 февраля) султан приказал в присутствии Лазарева выбить золотые и серебряные медали «в воспоминание» о присылке эскадры Николаем I. На одной стороне медали изображался вензель султана, а на другой турецкий герб - луна со звездой. «Медали сии тогда же были разосланы, как памятник, для хранения всем русским офицерам, в то время находившимся в Царьграде. - Странное столкновение противоположных мыслей и действий в турецком правительстве, где на каждом шагу видна борьба Порты с Султаном! В сем случае мнимый самодержец восторжествовал. Он не только призвал, вопреки общего мнения, союзников, но даже всенародно ознаменовал торжество бесславного союза - последнего убежища своего» (с. 203) чеканкой медали.

3 марта Муравьев получил через Одессу «повеление военного министерства от 14-го февраля, коим оно уведомляло о движении войск сухим путем и морем в Турцию. Распоряжение сие было сделано в следствие первого требования Портой вспомогательных войск, когда я еще был в Александрии. Назначалось на первый случай, кроме Черноморского 
флота, два сухопутных отряда: один для высадки в Босфоре, а другой... для подкрепления способов обороны со стороны Константинополя. Первый из сих отрядов поручался моему начальству...» (с. 208-209). Сообщалось и о подготовке десанта. «По соединении десантного отряда с сухопутным, генерал-адъютант Киселев принимал главное начальство над всеми войсками, и я поступал в команду его. До того же времени я обязан был посылать донесения свои прямо к военному министру, а Киселеву только для сведений» (с. 211). В «повелении» подробно предписывалось, как должны действовать войска...

«Распоряжения сии сохранялись еще нами в тайне, когда Рейс-эфенди пригласил нас троих (Муравьева, Бутенева, Киселева. - С. М.) на совещание, в намерении объявить нам о желании Султана, чтобы флот наш возвратился, на что он имел, как мы после узнали, от Султана письменное повеление, вынужденное настояниями вице-адмирала Руссена». Ненужность флота рейс-эфенди объяснил тем, что «флот мало мог сделать препятствия Ибрагиму, если б он пришел в Скутари». Бутенев объявил ему о скором прибытии вспомогательного войска «чем и прекратилось наше заседание». Чтобы «слух об ожидаемом десанте не распространился через Турок, я от Рейс-эфенди немедленно поехал к Сераскиру и объявил ему эту новость. Умный старец тотчас смекнул, что уже поздно было бороться против таких усиленных мер дружбы (хорошо сказано. - С. М.) и скрыл свое удивление» (с. 212).

«8-го числа барон Штюрмер, живший в Пере, приезжал к нам и показывал списки с наставлений, данных отправленным в Египет: Английскому полковнику Кампбелю и Австрийскому подполковнику Промешу. Оба должны были изъявить Мегмет-Али-паше неудовольствие дворов за возмущение его против Султана; но ни в той, ни в другой инструкции незаметно было угроз, - ограничивались одними убеждениями и советами» (c. 215-216).

Не вдаваясь во все сложные перипетии умиротворения египетского паши и его воинственного сына Ибрагима, подробно освещенные Муравьевым, кратко остановимся на событиях заключительного этапа, о которых генерал пишет: «По известиям ... из Александрии, доходили до нас сведения, что мир уже был заключен на условиях, предложенных Египтянами». 23-го числа сераскир и Ахмед-паша-мушир подтвердили, что «Порта точно заключила мир на этих условиях, но что Карамания отдана не Мегмет-Али, а Ибрагимпаше, ... не в виде владения, но на откуп, с тем, что Султан вправе, когда ему угодно, отдать Караманию другому». Когда Муравьев спросил турок «почему заключение мира было скрыто от нас столь долгое время ... Они уверяли ..., что договор этот был утвержден Султаном не более двух или трех дней тому назад ...» и сказали, что рейс-эфенди незамедлительно уведомит Бутенева о заключении мира (с. 326-327).

6 мая в Стамбул прибыл граф А.Ф. Орлов, назначенный полномочным послом при султанском дворе, начальником всех сухопутных и морских сил, находившихся в Босфоре. «Ему разрешено было объявить, кому сочтет за нужное, войну и, в случае надобности, открыть военные действия с находившимися у него под рукой войсками». Корпус генерал-адъютанта Киселева подчинялся ему «в случае движения, не взирая на то, что Киселев был в чине старше его» (с. 329-330). «Ахмед-паша лично передал Графу первые положительные известия о заключении мира ... Орлов ... изъявил удовольствие Государя за все нами сделанное до тех пор; но как будто упрекал в том, что Турки заключили мир без нашего согласия» (с. 331).

Но «едва кончалась завязчивая ссора между Султаном и Египетским пашей, как новые заботы обратили на себя внимание дипломатического сословия». В Смирну прибыл французский флот, «из Англии уже отправилось восемь линейных кораблей в Левант и соединенные флоты сии должны были, как говорили, двинуться к Дарданеллам». Муравьев сообщает, что 10 мая к нему приехал сераскир (непонятно, почему к нему, а не к Орлову. - С. М.) и известил, «что Ибрагим-паша занял войсками Кесарию, лежащую вне дороги отступления его в Сирию, как бы грозясь двинуться к границам Грузии. ... Казалось, что война вновь завязывалась. ... В народе вообще господствовало какое-то поверье, что дело решится только с совершенным падением Турецкой империи». Но в тот же день было доставлено первое положительное известие об отступлении неприятеля (с. 337-340).

Египетско-турецкое перемирие было заключено 14 мая 1833 г. в ставке Ибрагима в Кютахье при содействии французской дипломатии. Судя по «Запискам» Муравьева, это больно ударило по самолюбию автора, фактически добившегося нужного результата 
раньше французов, причем на более выгодных для Турции условиях. Теперь же Османская империя передала под управление Мехмед Али-паши Египет, Крит, Дамаск, Джидду и Адану. Повествуя об этих событиях, генерал отмечает, что около середины мая были получены официальные известия об отступлении Ибрагим-паши. Орлов послал капитана барона Ливена, а турки, по предложению Орлова, одного полковника «для следования за египетской армией до Таврских теснин. ... Мера сия была не столько нужна для удостоверения нашего, сколько для показания, что египетское войско как бы выпроваживалось под наблюдением русского офицера, чего не сделали ни Французы, ни Англичане» (с. 364). 24 июня (6 июля) султана известили, что египетские войска покинули Анатолию.

«Мир был заключен; но Султан, в объявлениях своих, назвал это не миром, а прощением, дарованным восставшему. Он наградил еще Мегмет-Али за мнимую покорность - Сирией, а Ибрагим-пашу - Аданою, прежде чего повинившиеся и не хотели отступать. По получении требованного, Ибрагим удостоил Султана благодарным письмом, которое было тщательно разглашено последним» (с. 364-365).

25 июня (7 июля) Орлов «уведомил падишаха об уходе последнего египетского солдата за Твырский хребет и “испросил” разрешения на возвращение домой экспедиционного корпуса», которое немедленно и получил. Граф оставался еще два дня в Буюк-Дере и «был на частной аудиенции у Султана, от коего получил письмо к государю, и после того отправился в Одессу на отдельном от флота ... корабле», увозя долгожданный договор.

Сразу после известия о том, что войска Ибрагима-паши ушли из Анатолии, началась эвакуация российского десантного отряда. 28 июня «поутру, нагруженный войсками флот, снялся с якоря и при благоприятном ветре вышел из Босфора с салютационной пальбой». Так кончилась, - пишет Муравьев, - «экспедиция наша на Босфор. Последствием ее был оборонительный союз между Россией и Турцией, заключенный графом Орловым с сераскиром» (с. 430-431).

Договор был заключен 26 июня (8 июля) в Ункяр-Искелеси. В.Н. Виноградов характеризует это событие как «взрыв дипломатической бомбы», отметив, что при подписании договора «Орлов вежливо, но твердо отклонил попытки своих турецких собеседников договориться о наступательном союзе»².

Договор состоял из шести статей и секретной статьи, содержание которых хорошо известно, и поэтому нет смысла приводить их здесь. Отметим только, что «иностранцы называют договор этот по названию Султанской долины, близ коей стоял лагерь: Traite d'Unkiar-Scelessi, как бы в упрек того, что договор написан под влиянием нашего оружия .... Иностранцев всего более оскорбляла секретная дополнительная статья, по коей воспрещалось военным судам их входить в Дарданеллы. Англичанам, в особенности ... так неприятна, что они вскоре после заключения договора требовали от нас к запретительному условию дополнения, по коему бы равно и нашим военным судам был воспрещен выход через Геллеспонт в Средиземное море, на что ... мы и согласились» (с. 431-433).

Особого внимания заслуживают суждения Муравьева об оборонительном союзе, якобы закрывающем Черное море от вторжения иностранцев. В доказательство ошибочности такого мнения генерал приводит три основных довода. Сейчас сложно определить, когда именно эти доводы созрели у генерала - сразу по заключении союза, чего нельзя исключать, принимая во внимание тактические и стратегические способности Муравьева, или по прошествии времени, когда рукопись готовилась к изданию. Думается, в любом случае они верны.

Доводы заключаются в следующем (цитата приводится почти целиком):

«1. Турецкое правительство никогда не будет в состоянии знать заблаговременно об угрожающей ему опасности, и потому нельзя даже будет обвинять Порту в лживости расположения ее к нам, если она не позовет нас вовремя на помощь.

2. Турецкий флот, по бездеятельности и слабости своей, не только не будет в состоянии противиться вторжению в Дарданеллы; но даже будет взят и присоединен к неприятельским силам для действия против нас.

3. Когда неприятельские эскадры, стоящие обыкновенно близ Смирны, захотят вторгнуться в Черное море, то они будут бомбардировать Одессу прежде, чем узнают в Петербурге о вторжении их, и войска наши не только не поспеют в Дарданеллы для обороны входа, но и не увидят Босфора прежде изгнания неприятеля из Черного моря ... 
Весь договор был написан без видимой обдуманности. Мелькали правдоподобие и возможность другой экспедиции; спешили кончить настоящую, опасаясь всеобщей войны в Европе, и думали положить основание будущего посещения нами Царьграда трактатом, сделанным без всякого поручительства со стороны Турок; ибо они, до последнего дня падения своего, могли еще признавать себя в силах держаться без нашей помощи.

Со своей стороны, Сераскир, заключая условие секретной статьи, знал, что Дарданелльские замки не в состоянии помешать вторжению неприятельского флота; но, давая высокую цену мнимым силам знаменитого пролива, уже давно пришедшим в ослабление, он делал нам угодное и, вместе с тем, имел с (надо “в”. - С. М.) виду скорейшее удаление наше. При том же, Порта всегда могла оправдаться в случае вторжения, несколькими выстрелами, пущенными с Дарданелльских батарей по неприятельским судам».

Муравьев признает, что «влияние наше сильно тяготело над политикой Турции, когда писали этот договор; Оттоманская империя была в состоянии одеревенелости, и царство Султана, направляемое тогда в действиях своих внушениями двора нашего, имело только признаки независимой самостоятельности. Такое положение было драгоценно; иностранные державы не могли обвинить нас в завоевании нового царства; нам не нужно было отделять особенных сил для удержания Дарданелл, а управлять силами самой земли, через посредство законных властей ее» (с. 433-434).

26 сентября 1833 г. Муравьев приехал в Петербург, 27-го встретился с графом Орловым (c. 446-447). Уже 1 октября в Царском Селе Муравьев был принят императором, который отметил, что успех миссии способствовал заключению Ункяр-Искелесийского договора и произвел Н.Н. Муравьева в генерал-адъютанты.

Завершая, еще раз подчеркнем тот факт, что мало кто верил в успех миссии Муравьёва, однако генерал блестяще справился с поставленной задачей, проявив выдающиеся дипломатические способности.

Идея оборонительного союза исходила от Турции и, как пишут турецкие историки, Россия «охотно пришла на помощь, вынудив принять это как свершившийся факт», обеспечив поддержку российских сил Махмуду II. «Сумев закрыть проливы для противников и открыть их для себя, Россия установила нечто вроде протектората над Османской империей, став ее защитницей; это сильно обеспокоило Европу» ${ }^{3}$.

Ункяр-Искелесийский договор был высшей точкой дипломатических успехов России на Ближнем Востоке. Договор действительно на короткое время усилил позиции России в Османской империи, повысил ее престиж в Стамбуле, на некоторое время ослабил влияние западноевропейских держав на Турцию. Соглашение укрепило международные позиции Порты, защитило ее от нового нападения Мехмеда-Али-паши и позволило заняться внутренними преобразованиями. Но, как показали дальнейшие события, на исходе срока действия Ункяр-Искелесийского договора (8 лет) ${ }^{4}$, обманчиво блеснувшего в дипломатической истории Восточного вопроса, Россия очутилась в полной изоляции.

${ }^{1}$ Русские на Босфоре в 1833 году. Из записок Н.Н. Муравьева (Карсского). - М.: Издание Чертковской библиотеки, 1869. (Далее в основном тексте в скобках будут указываться только страницы).

${ }^{2}$ Виноградов В.Н. Двуглавый орел на Балканах. 1683-1914. - М.: Индрик, 2010. - С. $262-264$.

${ }^{3}$ История Османского государства, общества и цивилизации: в 2 т. / Под ред. Э. Исханоглу; Исслед. центр исламской истории, искусства и культуры (IRCICA); пер. В.Б. Феоновой под ред. М.С. Мейера. - М.: Вост. лит., 2006. - С. 68-69.

${ }^{4}$ История Балкан. Век девятнадцатый (до Крымской войны). - М.: Изд-во: Эдиториал УРСС, 2012. - C. 424, 436. 